\title{
Immobilized Hydrogels for Screening of Molecular Interactions
}

\author{
Melissa M. Dominguez, Michel Wathier, Mark W. Grinstaff*, and Scott E. Schaus* \\ Departments of Biomedical Engineering and Chemistry, Metcalf Center for Science and \\ Engineering Building, Boston University \\ 590 Commonwealth Avenue, Boston, Massachusetts 02215
}

\section{Supporting Information}

General Information. ${ }^{1} \mathrm{H}-\mathrm{NMR},{ }^{19} \mathrm{~F}-\mathrm{NMR}$ and ${ }^{13} \mathrm{C}-\mathrm{NMR}$ were recorded on a Varian INOVA at 400, 376.309 and 100.6 MHz, respectively. Chemical shifts are reported in parts per million as follows: chemical shift, multiplicity $(\mathrm{s}=$ singlet, $\mathrm{d}=$ doublet, $\mathrm{t}=$ triplet, $\mathrm{q}=$ quartet, $\mathrm{m}=$ multiplet, $b r=$ broad) and integration. Chemical ionization mass spectra were obtained on a Hewlett-Packard HP 5988A spectrometer using $\mathrm{NH}_{3}$. Fast atom bombardment mass spectra (FABMS) were obtained on a JEOL JMS-SX102A spectrometer using a 3-nitrobenzyl alcohol matrix. MALDI-MS was performed by PerSeptive Biosystems Voyager-DE BioSpectrometer Workstation using 2-(4-hydroxyphenylazo)-benzoic acid (HABA). Elemental analysis was obtained from Atlantic Microlab, Inc. 384-well plates were purchased from Genetix (Boston, MA) and Super aldehyde slides were purchase from Telechem International (Sunnyvale, CA). Arrays were produced using an OmniGrid Accent ${ }^{\mathrm{TM}}$ Microarrayer (GeneMachines, San Carlos, CA). Fluorescence images were obtained on a GenePix 4000B fluorescence chip scanner and data analysis was done using GenePix 3.0 software (Axon Instruments, Union City, CA). All reactions were performed under nitrogen atmosphere. All solvents were dried and freshly distilled prior to use $\left(\mathrm{CH}_{2} \mathrm{Cl}_{2}\right.$ with $\mathrm{CaH}_{2}$ and $\mathrm{MeOH}$ with $\left.\mathrm{Na}\right)$ or were purchased from Acros (DMF) and Sigma (DMSO). All other chemicals were purchased from Aldrich, Acros or CHEM IMPEX as highest purity grade and used without further purification. Other reagents were used as supplied by Sigma-Aldrich, Ambion, Alfa Aesar, Lancaster, and Acros unless otherwise noted. Proteins were purchased from Sigma (BSA, Goat-IgG and Cy5-Streptavidin conjugate) and Pierce (protein G). BSA for control experiment was purchased from invitrogen. DNA 20mers (5'-TGAGTCTTCTAAGCTCTCCG-3' and 5'-Cy5-CGGAGAGCTTAGAAGACTCA-3') were purchased from Sigma-Genosys. Poly-Adenosine was purchased from Sigma. Cy5 monofunctional ester was purchased from Amersham. Gel filtration was performed using Sephadex 10-fine, purchased from Sigma. Microcon's ${ }^{\mathrm{TM}}$ were purchased from Millipore (Billerica, MA). NanoPure ${ }^{\mathrm{TM}}$ water (Barnstead International, Dubuque, Iowa) was used for all solutions and procedures requiring water, unless otherwise noted. $\mathrm{DCC}=$ dicyclohexylcarbodiimide, $\mathrm{DCU}=1,3$-dicyclohexylurea, $\mathrm{Pd} / \mathrm{C}=10 \%$ palladium on activated carbon, PFP $=2,3,4,5,6$-pentafluorophenol, DIEA $=$ diisopropylethyl amine, HOBT = hydroxybenzotriazol, $\mathrm{PEG}=$ polyethylene glycol, $\mathrm{PBS}=$ Phosphate-buffered saline, $\mathrm{PBST}=$ PBS with Tween $201 \%$, SSC = sodium chloride sodium citrate, EDTA = ethylenediaminetetraacetic acid, BSA $=$ Bovine Serum Albumin, SDS $=$ Sodium dodecyl sulphate. 


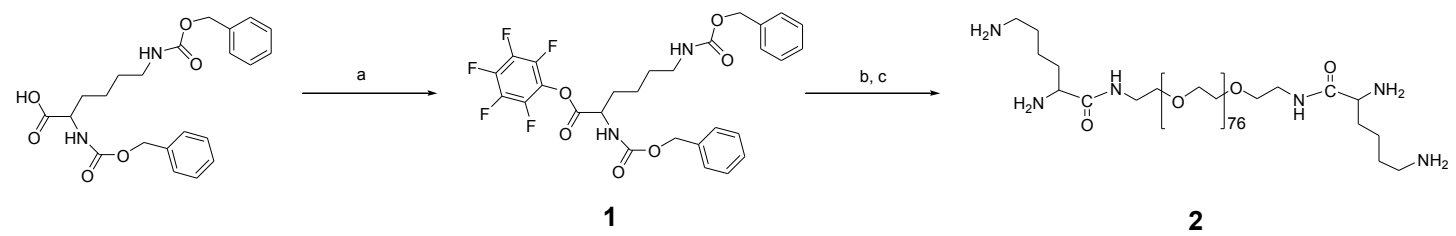

a) PFP, DCC, $\mathrm{CH}_{2} \mathrm{Cl}_{2}, 25^{\circ} \mathrm{C}$ for $24 \mathrm{~h}, 98 \%$ yield; b) PEG Diamino Mw 3400, DIEA, HOBT, DCM, 24h, 95\% yield; c) $\mathrm{H}_{2} / \mathrm{Pd} / \mathrm{C}, \mathrm{MeOH}, 6 \mathrm{~h}, 99 \%$ yield.

Synthesis of ZLys(Z)OPFP (1). DCC (5.45 g, $26 \mathrm{mmol})$ in $\mathrm{CH}_{2} \mathrm{Cl}_{2}(20 \mathrm{~mL})$ was added in five portions over 10 minutes to a solution of ZLys(Z)OH (10 g, $24 \mathrm{mmol})$ and PFP (4.49 g, 26 mmol) in freshly distilled $\mathrm{CH}_{2} \mathrm{Cl}_{2}(40 \mathrm{~mL})$. The reaction mixture was stirred under $\mathrm{N}_{2}$ at $25{ }^{\circ} \mathrm{C}$ for $2 \mathrm{~h}$, filtered to remove the insoluble DCU, concentrated to $\sim 20 \mathrm{~mL}$ under reduced pressure, and then stored at $4{ }^{\circ} \mathrm{C}$ for $2 \mathrm{~h}$. An additional filtration removed further urea, and the solution was then diluted with hexane $(25 \mathrm{~mL})$ and stored at $4{ }^{\circ} \mathrm{C}$ for $4 \mathrm{~h}$. The resultant white precipitate was collected by filtration, washed with $\mathrm{CH}_{2} \mathrm{Cl}_{2} /$ hexane $(1: 2,3 \times 5 \mathrm{~mL})$, and dried under vacuum; yield $13.37 \mathrm{~g}$ (98\% yield).

${ }^{1}$ H NMR $\left(400 \mathrm{MHz}, \mathrm{CDCl}_{3}\right) \delta 1.46\left(\mathrm{~m}, 2, \mathrm{CH}_{2}-\mathrm{CH}_{2}\right) ; 1.54\left(\mathrm{~m}, 2, \mathrm{CH}_{2}-\mathrm{CH}_{2}\right) ; 1.84\left(\mathrm{~m}, 1, \mathrm{CH}_{2}-\right.$ $\mathrm{CH}) ; 2.00$ (m, 1, $\left.\mathrm{CH}_{2}-\mathrm{CH}\right) ; 3.19$ (m, 2, $\left.\mathrm{CH}_{2}-\mathrm{NH}\right) ; 4.67$ (m, 1, $\left.\mathrm{CH}_{2}-\mathrm{CH}\right) ; 4.8$ (m, 1, NH); 5.03 (m, 2, $\left.\mathrm{CH}_{2}-\mathrm{O}\right) ; 5.11\left(\mathrm{~s}, 2, \mathrm{CH}_{2}-\mathrm{O}\right) ; 5.54(\mathrm{~m}, 1, \mathrm{NH}) ; 7.3(\mathrm{~m}, 10$, arom $\mathrm{CH})$.

${ }^{13} \mathrm{C}$ NMR $\left(100.6 \mathrm{MHz}, \mathrm{CDCl}_{3}\right): \delta 22.63\left(\mathrm{CH}_{2}\right) ; 30.06\left(\mathrm{CH}_{2}\right) ; 32.10\left(\mathrm{CH}_{2}\right) ; 40.72\left(\mathrm{CH}_{2}-\mathrm{NH}\right)$; $54.33(\mathrm{CH}) ; 67.44$ and $68.04\left(\mathrm{CH}_{2}-\mathrm{O}\right) ; 128.78-129.22(\mathrm{CH}$ arom $) ; 136.61$ and $137.13(\mathrm{C}$ arom $)$; 156.61-157.38 (CO-O-NH); 169.48 (CO ester);

${ }^{19}$ F NMR (376.309 $\left.\mathrm{MHz} \mathrm{CDCl}_{3}\right): \delta-162.26(\mathrm{t}, 2 \mathrm{~F}),-157.60(\mathrm{t}, 1 \mathrm{~F}),-152.72(\mathrm{~d}, 2 \mathrm{~F})$;

FAB-MS $m / z$ calc'd $\left(\mathrm{MH}^{+}\right)$580.5, found: 581.7 ;

Elemental analysis: (calc'd for C, 57.93; H, 4.34) found: C, 58.12; H, 4.40.

Synthesis of Bis(2-amido-Zlys(Z))-poly(ethylene glycol). Polyethylene glycol diamino $\mathrm{Mw}=3400 \mathrm{~g} / \mathrm{mol}(1 \mathrm{~g}, 0.3 \mathrm{mmol})$ was dissolved in DCM $(5 \mathrm{~mL})$ and then DIEA $(113 \mathrm{mg}, 0.9$ mmol) was added. After $5 \mathrm{~min}$ the ZLys(Z)OPFP (500 $\mathrm{mg}, 0.9 \mathrm{mmol})$ in $\mathrm{CH}_{2} \mathrm{Cl}_{2}(5 \mathrm{~mL})$ was added at $0{ }^{\circ} \mathrm{C}$. The reaction mixture was stirred for $24 \mathrm{~h}$ at $25{ }^{\circ} \mathrm{C}$ under $\mathrm{N}_{2}$. After concentration under vacuum the mixture was dissolved in DCM $(100 \mathrm{~mL})$ and washed with $\mathrm{NaHCO}_{3}(2 \times 100$ $\mathrm{mL})$, water $(2 \times 100 \mathrm{~mL})$, and then dried over $\mathrm{Na}_{2} \mathrm{SO}_{4}$. Evaporation of the organic solvent gave an oil that was purified by precipitation in cool ether to lead a white powder $1.14 \mathrm{~g}$ (95\% yield).

${ }^{1}$ H NMR (400 MHz, DMSO d $\left.)_{6}\right): \delta 1.33,1.48,1.61-1.77\left(\mathrm{~m}, 12, \mathrm{CH}_{2}-\mathrm{CH}_{2}\right) ; 3.13$ (m, 4, $\mathrm{CH}_{2}$ $\mathrm{NH}) ; 3.41$ (m, 4, $\left.\mathrm{CH}_{2}-\mathrm{NH}\right) ; 3.55-3.80$ (m, 340, PEG); 4.10 (m, 2, CH); 4.99 (m, 2, NH); 4.99$5.04\left(\mathrm{~m}, 8, \mathrm{CH}_{2} \mathrm{Z}\right) ; 5.61(\mathrm{~m}, 2, \mathrm{NH}) ; 6.60$ (m, 2, NH); 7.24-7.30 (m, 20, Arom).

${ }^{13}$ C NMR (100.6 MHz, $\left.\mathrm{CDCl}_{3}\right): \delta 22.30,29.37,32.42\left(\mathrm{CH}_{2}\right) ; 39.31,40.42\left(\mathrm{CH}_{2} \mathrm{NH}\right) ; 54.81$ $(\mathrm{CH}) ; 66.52\left(\mathrm{CH}_{2} \mathrm{O}\right) ; 69.60-70.62(P E G) ; 128.19-128.63$ (CH Arom); 136.47, 136.82 (C Arom); 156.31-156.75 (CONH); 171.85 (CO-NH PEG);

MALDI-TOF MS: $m / z$ calc'd $\left(\mathrm{MH}^{+}\right)$4164, found: 4153 .

Synthesis of Bis(2-amido-lysine)-poly(ethylene glycol) (2). $\mathrm{Pd} / \mathrm{C}(10 \% \mathrm{w} / \mathrm{w})$ was added to a solution of Bis(2-amido-Zlys(Z))-poly(ethylene glycol) (1 g, $0.24 \mathrm{mmol})$ in $\mathrm{MeOH}(50 \mathrm{~mL})$. The flask for catalytic hydrogenolysis was evacuated and filled with $50 \mathrm{psi}$ of $\mathrm{H}_{2}$ before shaking for $10 \mathrm{~h}$. The catalyst was removed by filtration and the catalyst was washed with $\mathrm{MeOH}(20 \mathrm{~mL})$. The solution containing the product was neutralized with $\mathrm{HCl} 1 \mathrm{M}$ until $\mathrm{pH}=7$. The solution was 
evaporated then the compound was precipitated in cool ether to give $780 \mathrm{mg}$ of the white compound ( $99 \%$ yield).

${ }^{1} \mathbf{H}$ NMR (400 MHz, DMSO-d $\left.{ }_{6}\right) \delta$ 1.29-1.46 (m, 12, $\left.\mathrm{CH}_{2}-\mathrm{CH}_{2}\right) ; 2.69$ (m, 4, $\left.\mathrm{CH}_{2}-\mathrm{NH}\right) ; 3.18$ (m, 2, $\left.\mathrm{CH}_{-\mathrm{NH}_{3}}{ }^{+}\right) ; 3.28\left(\mathrm{~m}, 4, \mathrm{CH}_{2}-\mathrm{NH}_{3}{ }^{+}\right) ; 3.40-3.62$ (m, 340, $\mathrm{CH}_{2}$ of PEG); 8.01 (m, 2, NH).

${ }^{13}$ C NMR (100.6 MHz, $\left.\mathrm{CDCl}_{3}\right) \delta$ 22.40, 30.32, $32.01\left(\mathrm{CH}_{2}\right) ; 53.00(\mathrm{CH}) ; 170.00-172.34$ (CO$\mathrm{NH}$;

MALDI-TOF MS $m / z$ calc'd $\left(\mathrm{MH}^{+}\right)$3632, found: 3620 .

\section{General procedure for printing molecules on glass slides.}

We initially screened the four different macromers shown in Figure SI1 for preparation of the hydrogel chambers. All four macromers in the presence of the $(\mathrm{CHO})_{2}-\mathrm{PEG}$ formed hydrogel chambers on the aldehyde coated glass slides. However, we found (Lys) $)_{2}$-PEG to be optimal since it formed a hydrogel chamber for all substrates tested. Specifically, we used an OmniGrid Accent ${ }^{\mathrm{TM}}$ microarraying robot equipped with a Stealth Printhead containing

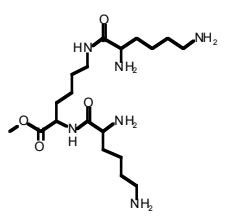

[G1]-Lys $-\mathrm{NH}_{2}$

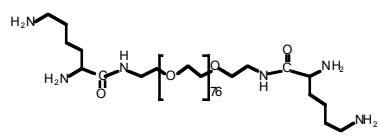

2: (Lys) $)_{2}$-PEG

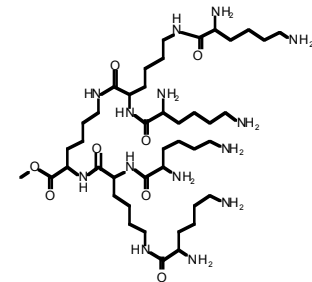

[G2]-Lys- $\mathrm{NH}_{2}$

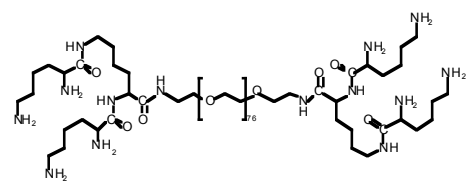

$\left.(\text { Lys })_{2}\right)_{2}$-PEG

Figure SI1. The four different macromers investigated for formation of the hydrogel chambers.

dispense $1 \mathrm{~nL}$ volumes of the hydrogel precursors (aqueous solution; $\mathrm{pH}=7.4 ; 17 \% \mathrm{w} / \mathrm{w}$ polymer) plus the printing molecule/macromolecule on the aldehyde-coated glass slides. Using this mechanical printing technique, one can print $\approx 50,000$ torroid-like reaction chambers on an $18 \times 72 \mathrm{~mm}$ glass slide. The reaction chambers are torroid-like in shape due to the mechanical printing of the crosslinking hydrogel which is transforming from a low viscous solution to a viscoelastic. After printing, the slides were washed with $1 \% \mathrm{w} / \mathrm{w} B S A$ in $\mathrm{PBS}(\mathrm{pH}=7.4)$ to block the remaining surface aldehydes.

Goat-IgG. $1 \mu \mathrm{L}$ of a $1.8 \mathrm{mg} / \mathrm{mL}$ solution in water was transferred to a 384-well plate. To the well was successively added $1.5 \mu \mathrm{L}$ of solution containing (Lys) $)_{2}$ PEG $(2.1 \mathrm{mg}$ in $15 \mu \mathrm{L}$ of HEPES $100 \mathrm{mM}, \mathrm{pH} 7.4$ ), $4 \mu \mathrm{L}$ of solution containing the PEG(DA) (26 mg in $40 \mu \mathrm{l}$ of HEPES $100 \mathrm{mM}, \mathrm{pH} 7.4$ ), and $9.5 \mu \mathrm{L}$ of HEPES (100 mM, pH 7.4) to give a $112 \mu \mathrm{g} / \mathrm{mL} \mathrm{IgG} \mathrm{in} 17 \mathrm{wt} \%$ 2:1 PEG-Ald:PEG-Lys. Solutions were also prepared without IgG to serve as blanks. These solutions were then printed onto aldehyde slides and were left overnight to allow for hydrogel formation. Slides were then immersed in a solution of $1 \% \mathrm{BSA}(\mathrm{w} / \mathrm{v})$ in $\mathrm{PBS} \mathrm{pH} 7.4$ and gently agitated on an orbital-shaker for $15 \mathrm{~min}$ at room temperature. Slides were then rinsed for $1 \mathrm{~min}$ in PBS pH 7.4, followed by $1 \mathrm{~min}$ in water. Slides were then dried by centrifugation for $2 \mathrm{~min}$ at $100 \mathrm{~g}$.

Biotin. Microarrays were prepared from a printing solution of $0.62 \mu \mathrm{g} / \mathrm{mL}$ biotin in hydrogel solution as described above. 
RNA. Microarray gels were prepared from a printing solution of $0.50 \mu \mathrm{g} / \mathrm{mL}$ whole aRNA in hydrogel solution as described above.

DNA. Microarray gels were prepared from a printing solution of 103 pM 20 -mer DNA in hydrogel solution as described above.

General procedure for the preparation of Cy5 conjugated proteins. Protein G conjugate. In general, proteins were labeled using 1:28 mol equivalents of protein to dye at a concentration of $1 \mathrm{mg} / \mathrm{mL}$ in $0.1 \mathrm{M} \mathrm{Na}_{2} \mathrm{CO}_{3}(\mathrm{pH} 9.2$ ). Specifically, $26 \mu \mathrm{l}$ of a $3.7 \mathrm{mg} / \mathrm{ml}$ solution of protein $\mathrm{G}(0.1$ $\mathrm{mg}$ ) in PBS pH 7.4 were transferred to a microcentrifuge tube containing $74 \mu \mathrm{l}$ of $0.1 \mathrm{M} \mathrm{Na}_{2} \mathrm{CO}_{3}$ ( $\mathrm{pH}$ 9.2). The solution was then transferred to a vial containing $0.1 \mathrm{mg}$ of Cy5 monofunctional succinimidyl ester. The solution was incubated in the dark for $40 \mathrm{~min}$ at room temperature with occasional vortexing. Cy5-protein $\mathrm{G}$ conjugate was separated from non-conjugated dye via gel filtration. Labeled protein was then concentrated using Microcon ${ }^{\mathrm{TM}} 10$ 's to a concentration of $166 \mu \mathrm{g} / \mathrm{mL}$.

Cy5-streptavidin conjugate. $0.5 \mathrm{mg}$ of streptavidin was labeled as described above (76 mol Dye/1 mol streptavidin). Cy5-streptavidin conjugate was separated from non-conjugated dye using Microcon ${ }^{\mathrm{TM}} 30$ 's and resuspended in $1 \mathrm{~mL}$ PBS to give a concentration of $0.5 \mathrm{mg} / \mathrm{mL}$.

Hybridization of IgG hydrogels with Cy5-protein G conjugate. $4 \mu \mathrm{l}$ of a $166 \mu \mathrm{g} / \mathrm{mL}$ solution of Cy5-protein $\mathrm{G}$ conjugate was transferred to a microcentrifuge tube and $20 \mu \mathrm{L}$ of PBS supplemented with $0.1 \%$ Tween 20 (PBST) was added. The $28 \mu \mathrm{g} / \mathrm{mL}$ Cy5-protein conjugate probe solution was vortexed, quickly centrifuged and applied between the coverslip and the microscope slide containing the dendrimer gel pads. The slide was hybridized for $1 \mathrm{hr}$ at room temperature in a hybridization chamber containing $3 \mathrm{xSSC}$ for humidification. Slides were rinsed

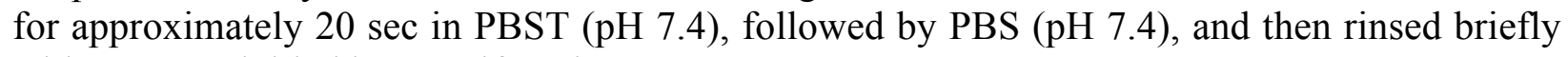
with water and dried by centrifugation.

Hybridization of biotin hydrogels with Cy5-streptavidin conjugate. Briefly stated, the probe solution consisted of Cy5-streptavidin $(2 \mu \mathrm{g} / \mathrm{mL})$, EDTA $(1 \mathrm{mM}), 1 \%$ BSA and $15 \mu \mathrm{L}$ Ambion's Slidehyb ${ }^{\mathrm{TM}}$ buffer 2 . The solution was vortexed and heated at $80^{\circ} \mathrm{C}$ for a few seconds. $24 \mu \mathrm{L}$ of the probe solution was applied under the coverslip. The slide was hybridized for $1 \mathrm{hr}$ at room temp in a hybridization chamber containing $3 \mathrm{xSSC}$ for humidification. Slides were rinsed three times with PBS ( $\mathrm{pH}$ 7.4) for three minutes each, then rinsed with water and dried by centrifugation.

Hybridization of RNA hydrogels with Cy5-aRNA. RNA used in these screens was produced from total RNA isolated from Saccharomyces cerevisiae using the RNeasy ${ }^{\mathrm{TM}}$ kit (Ambion, Austin, TX). Poly-A RNA was isolated using Oligotex ${ }^{\mathrm{TM}}$ resin (Qiagen, Valencia, CA). The poly-A RNA was amplified using the aRNA kit from Ambion. $2 \mu \mathrm{g}$ of aRNA was labeled with Cy5 monofunctional succinimidyl ester and separated form non-conjugated dye according to Ambion's aRNA protocol. Labeled aRNA was fragmented into 60-200 nucleotide strands using Ambion's fragmentation buffer (Austin, TX) and used without further processing. Briefly stated, the probe solution consisted of Cy5-aRNA $(83 \mu \mathrm{g} / \mathrm{mL}), 0.29 \mu \mathrm{g} / \mathrm{mL}$ EDTA, $1.25 \mathrm{mg} / \mathrm{mL}$ poly-A 
(Sigma, St. Louis, MO) and $16 \mu \mathrm{L}$ Ambion's Slidehyb ${ }^{\mathrm{TM}}$ buffer 2. Cy5-aRNA was then heated at $80^{\circ} \mathrm{C}$ for $2 \mathrm{~min}$, quickly spun and then heated for a few seconds before applying to slide. Slides were incubated at $48^{\circ} \mathrm{C}$ for $5 \mathrm{hr}$ then first washed in a solution of buffer $(90 \mathrm{mM} \mathrm{NaCl}, 9$ $\mathrm{mM}$ NaCitrate, $\mathrm{pH} 7.0)$ and SDS (3.5 mM), and then in a second buffer solution $(7.5 \mathrm{mM} \mathrm{NaCl}$, $0.75 \mathrm{mM}$ NaCitrate, $\mathrm{pH}$ 7.0). The slide was rinsed with water and dried by centrifugation.

Hybridization of DNA hydrogels with Cy5-DNA. Briefly stated, the probe solution consisted of $83 \mu \mathrm{g} / \mathrm{mL}$ 5'Cy5-DNA 20-mer, $0.29 \mu \mathrm{g} / \mathrm{ml}$ EDTA, $1.25 \mathrm{mg} / \mathrm{mL}$ poly-A, $0.21 \mathrm{mg} / \mathrm{mL}$ nonacetylated BSA, and $15 \mu \mathrm{L}$ Ambion's Slidehyb ${ }^{\mathrm{TM}}$ buffer 3 . Probe solution was heated at $80^{\circ} \mathrm{C}$ for $2 \mathrm{~min}$, spun and heated again for a few seconds before applying to slide. Slides were incubated at $48^{\circ} \mathrm{C}$ for $16 \mathrm{hr}$ and then first washed in a solution of buffer $(90 \mathrm{mM} \mathrm{NaCl}, 9 \mathrm{mM}$ NaCitrate, $\mathrm{pH}$ 7.0) and SDS (3.5 mM sodium dodecyl sulfate), and then in a second buffer solution (7.5 mM NaCl, $0.75 \mathrm{mM} \mathrm{NaCitrate,} \mathrm{pH}$ 7.0). The slide was rinsed with water and dried by centrifugation.

Control Experiments. Microarrays containing IgG, non-acetylated BSA, and blank gels were printed on a slide and probed with a Cy5-protein G solution as described previously. In both cases no significant increase in fluorescence (less than 18\%) was observed indicating that hybridization had not occurred and that the non-complementary protein did not get trapped within the hydrogel chambers.

In order to obtain optimal hybridization with respect to background and minimize non-specific binding for the nucleic acid experiments, we had to determine the stringency and blocking conditions ideal for our reaction chamber system. For our initial experiments, we used the commercially available Slidehyb survey kit of hybridization buffers and roughly followed the manufacturer's protocols. We further experimented by adding varying amounts of Poly-A and BSA as blocking materials and by changing hybridization length and temperature. We also tried a hybridization protocol based on a non-formamide based hybridization solution. The stringencies of the post-hybridization wash solutions were also varied. The procedures described above represents the conditions that resulted in the highest specificity relative to control gels, and therefore minimized non-specific binding while still maintaining an acceptable signal to noise ratio.

Fluorescence image analysis. The fluorescence intensities are calculated as the mean intensity of the spot normalized to the background. These values were used to determine specificity of gels containing compounds relative to blank gels. Cy5 dyes were used since there was some green background fluorescence in the hydrogel chambers. The fluorescence intensities were calculated as the mean intensity of the hydrogel chambers normalized to the background (glass slide). These values were used to determine specificity of hydrogel chambers containing compounds relative to control (hydrogel chambers without compound). $\mathrm{p}$ values were calculated using Student's t-Test. 